\title{
School Principal Entrepreneurial Competency Development Model to Optimize Generating Production Unit Income
}

\author{
Sitti Roskina Mas* \\ Abd. Kadim Masaong \\ Arifin Suking \\ Department of Educational Management, \\ Faculty of Education, Gorontalo State University, \\ Jl. Jend Sudirman No.6, Dulalowo Tim., Kota Tengah, \\ Kota Gorontalo, Gorontalo 96128, Indonesia \\ *Corresponding Author
}

DOI: https://doi.org/10.36941/jesr-2021-0110

\begin{abstract}
Vocational High School principals have vital competencies in developing their infrastructure, teachers, and students to ensure the graduates have sufficient ability in entrepreneurship and provide products/services in a production unit. To achieve these aims and generate profit, the entrepreneurial instinct of the principal is essential. The purposes of this study were (1) mapping the entrepreneurial potential of school principals, (2) mapping school resource and area resource that can be developed as an income-generating, and (3) designing a model for developing the entrepreneurial competence of school principals to optimize the income-generating production/service units of public vocational high schools in Tomini Bay area. This study has conducted three stages to create an appropriate developing model for an income-generating production/service unit optimization, namely, planning, implementation, and monitoring-evaluation. The result was that the entrepreneurial potential of vocational high school principals in Tomini Gulf area is in good category. This indicates that the principals demonstrated good entrepreneurial competencies in terms of creativity, innovation, motivation, diligence, and finding solutions.
\end{abstract}

Keywords: Entrepreneurial competence, income generating, school production units, school principals

\section{Introduction}

Entrepreneurial competence is one of the competencies that should be owned by school principals. In education sector, the context of entrepreneurship is strengthening the drift, values and enthusiasm of entrepreneurship (which prominent characteristics), such as being innovative, creative, hardworking, strong motivation, perseverant, and always looking for the best solutions in developing schools to achieve school success. Entrepreneurial competence for vocational high school (VHS) principals is very important compared to academic high school principals in order to optimally develop school production units that function as a means of learning and generating financial benefits, due tone of this school purposes is to ensure that the graduates will be independent, work-ready and has middle 
level entrepreneurship capability. As for competencies, the students with better skills will be more ready to work and compete in the global era (Birdthistle et al., 2016; Mas, 2015). For this reason, vocational high school is given an entrepreneurial forum in the form of a business institution, namely the production or service units as an incorporated entrepreneur that should be managed professionally and properly. To achieve this particular purpose, the school principals is required to have good entrepreneurial competence in order to optimize all the potential (resources) owned into a source of income (income generating) school production or service unit (Suyitno, 2018).

Considering that entrepreneurial competence is very important for school principals, especially for VHS principals, it is necessary to conduct a study on the entrepreneurial competence of school principals in managing vocational high school production units in Tomini Gulf area. The results of this study are expected to give a positive contribution to VHS to increase the income of the school, teachers, students, staff, and all parties involved in managing school production units, and at the same time improving the school member welfare. It will bring many benefits, especially for students as directly involved in the school production unit activities, thus enrich learning entrepreneurship experience. Furthermore, it will give them the opportunity to innovate the business, therefore can increase the graduate competitiveness and increase the positive image for the vocational school at the same time.

This reflects a highlighting situation VHS faces the challenge of producing graduates whose competencies are in accordance with the requirements of the contemporary business sector (Marniati \& Witcjaksono, 2020). Formal education in developing entrepreneurs has had a much higher impact on the economic wealth of the country (Wurthmann, 2014) and this is evidenced by the rapidly increasing number of entrepreneurship programs and courses at universities around the world (Piperopoulos \& Dimov, 2015). An entrepreneur can be seen as someone who takes innovative risks, manages and manages the resources of a company to generate long-term benefits (Iwu et al., 2019). Promoting entrepreneurship to stimulate economic development and job creation is increasingly important to do. In this sense, entrepreneurship education is considered a key instrument for increasing entrepreneurial intentions in the face of increasingly fierce business competition (San-Martín et al., 2019).

In order to make an effective tool in assessing the promotion of social entrepreneurship in higher education, a project mechanism is needed that will analyze the specific features of the entrepreneurial competency domain (Capella-Peris et al., 2020). Entrepreneurship education programs are increasingly established and expanded in learning in schools in an effort to equip students with the knowledge and competencies needed to create economic and employment value (Duval-Couetil, 2013). One of the tasks of entrepreneurship research is to investigate entrepreneurial intentions, as cognitive procedures lead to actual entrepreneurial behavior in the future (Kallas, 2019). Entrepreneurship is becoming an increasingly viable option for more and more young people to enter the labor market, so it is important to identify and develop good practices in the delivery of entrepreneurship training (Jackson, 2015).

The final result of this study is to create a design model to develop the entrepreneurial competence of school principals to optimize the income generating school production units. The results of this study are expected to provide various solutions for problems encounter in the management of VHS production or service units in Tomini Gulf area. The results of this study are also expected to bring positive impacts on either principal of academic high schools or VHS principals regarding how to develop the potential (resources) of the school into a business unit to get financial benefits although with limited resources through strategic ways, partnering with other institutions to create innovative, comparative and competitive advantages in school business units.

\section{Method}

\subsection{Research Design}

This study used research \& development method refers to Gall et al. (2003). This method selection became one of the domains on educational study to develop innovative activity models, in this 
context the principal entrepreneurial competency development model is to maximize income generating. The model stages contained five steps, namely: (1) preliminary study to analyze the product development, (2) develop preliminary form of product, (3) expert validation and revision, (4) small-scale field trial and product revision, and (5) large-scale field trial and final product. In this study, although only three stages have been implemented properly, model for developing the entrepreneurial competence for school principals to support the optimization of income-generating of VHS in Tomini Gulf area has already been found. Small-scale trials and product revision, as well as large-scale trial was carried out in subsequent studies.

\subsection{Research population and Sample}

The population of this research was all school vocational principals that consisted of 40 principals in Gorontalo Province, Indonesia. The research used purposive sampling comprised 22 school principals at public VHS in Bone Bolango, Pohuwato, and Boalemo Regencies in Gorontalo Province, Indonesia. The majority of all school principals' participants were male (18/22 participant) and had been to be school principals for more than four years. The purposive sampling was chosen according to geographical condition and the development of Tomini Bay for implementing the vision and missions of the State University of Gorontalo. It was also chosen because vocational school principals knew well about entrepreneurship and school innovation so that the research objectives could be achieved.

\subsection{Research Instrument and Procedure}

The study instrument was used a closed questionnaire according to the previous study (Mas and Suking, 2020) for measuring the entrepreneurial potency of VHS's principals. An open questionnaire was used to obtain the potency of the production unit of VHS. Closed and open questionnaires were distributed and responded by the participants directly in the school or indirectly through email. Other instruments were structured and in-depth interviews, observation, and documentation study directly to the principal VHS to obtain qualitative data for supporting the quantitative data.

\subsection{Data Analysis}

Data collected from open questionnaires were analyzed qualitatively to describe the study results. Closed questionnaire data obtained from respondents were analyzed using descriptive quantitative analysis using the formula as each item in the questionnaire was moved on the table to obtain a description of the percentage achieved in the questionnaire on each indicator and alternative answer, while data obtained from interviews, observation and the documentation study were analyzed in qualitative description presented through narration and figures to support the questionnaire results.

\subsection{Ethics}

Informed consent was obtained from all individual participants included in the study and confirmed that they are willing to be the participant. The research has been approved by Gorontalo State University ethical committee.

\section{Results}

3.1 Entrepreneurial Potential of Principals Based on İndicators Creativity and innovation.

The results are presented in the following Table 1. 
Table 1: The Result of Creativity and Innovation Indicator

\begin{tabular}{lccc}
\hline No & Indicator & Average Score of Sub Indicator & Percentage (\%) \\
\hline 1 & Creativity and innovation & 88 & $81 \%$ \\
\hline
\end{tabular}

3.2 Diligence and finding solutions.

The results are presented in the following Table 2.

Table 2: The Result of Diligence and Finding Solution Indicator

\begin{tabular}{lccc}
\hline No & Indicator & Average Score of Sub Indicator & Percentage (\%) \\
\hline 1 & Diligence and finding solution & 94 & $81 \%$ \\
\hline
\end{tabular}

\subsection{Motivational work.}

The results are presented in the following Table 3.

Table 3: The Result of Motivational Work Indicator

\begin{tabular}{llcc}
\hline No & Indicator & Average Score of Sub Indicator & Percentage (\%) \\
\hline $\mathbf{1}$ & Work motivation & 98 & $89 \%$ \\
\hline
\end{tabular}

\subsection{Entrepreneurial drift.}

The results are presented in the following Table 4 .

Table 4: The Result of Entrepreneurial

\begin{tabular}{lccc}
\hline No & Indicator & Average Score of Sub Indicator & Percentage (\%) \\
\hline 1 & Entrepreneurial drift & 85 & $78 \%$ \\
\hline
\end{tabular}

Based on these data, the average of the potential for entrepreneurial leadership of the principals in Tomini Gulf is in the good category as shown in Table 5.

Table 5: The Percentage Summary of Entrepreneurial Competence of Vocational High School Principals in Tomini Gulf Area

\begin{tabular}{llccc}
\hline No Indicator & Average Score of Sub Indicator & Percentage (\%) & Category \\
\hline 1 & Creativity and Innovation & 88 & $81 \%$ & Good \\
2 & Diligence and Finding Solution & 94 & $81 \%$ & Good \\
3 & Work Motivation & 98 & $89 \%$ & Good \\
$4 \quad$ Entrepreneurial Drift & 85 & $78 \%$ & Sufficient \\
\hline Average & 91 & 82 & Good \\
\hline
\end{tabular}

\subsection{The Potential of School Land Area Resources in The Gulf of Tomini}

Potential of school land area resources that can be developed as income generating vocational high school production or service units in Tomini Gulf area are presented in the following Table 6 and Table 7. 
Table 6: School Resources Potential

\begin{tabular}{lc}
\hline School Resources Potential & Percentage \\
\hline Human Resource & $30 \%$ \\
Infrastructure & $20 \%$ \\
Functional Land & $35 \%$ \\
Funding & $10 \%$ \\
Marketing & $5 \%$ \\
\hline
\end{tabular}

Table 7: Area Resources Potential

\begin{tabular}{lc}
\hline Area Resources Potential & Percentage \\
\hline Agriculture & $73 \%$ \\
Husbandry & $10 \%$ \\
Fishery & $10 \%$ \\
Tourism & $5 \%$ \\
Industry & $2 \%$ \\
\hline
\end{tabular}

The final result of this study is to find the best model for developing the entrepreneurial competence of school principals to optimize the income generating vocational high school production or service units in the Tomini Gulf area. The model contains three stages, namely: stage I planning, stage II implementation of the model, and stage III monitoring and evaluation of the model. Overall, the model is described as follows.

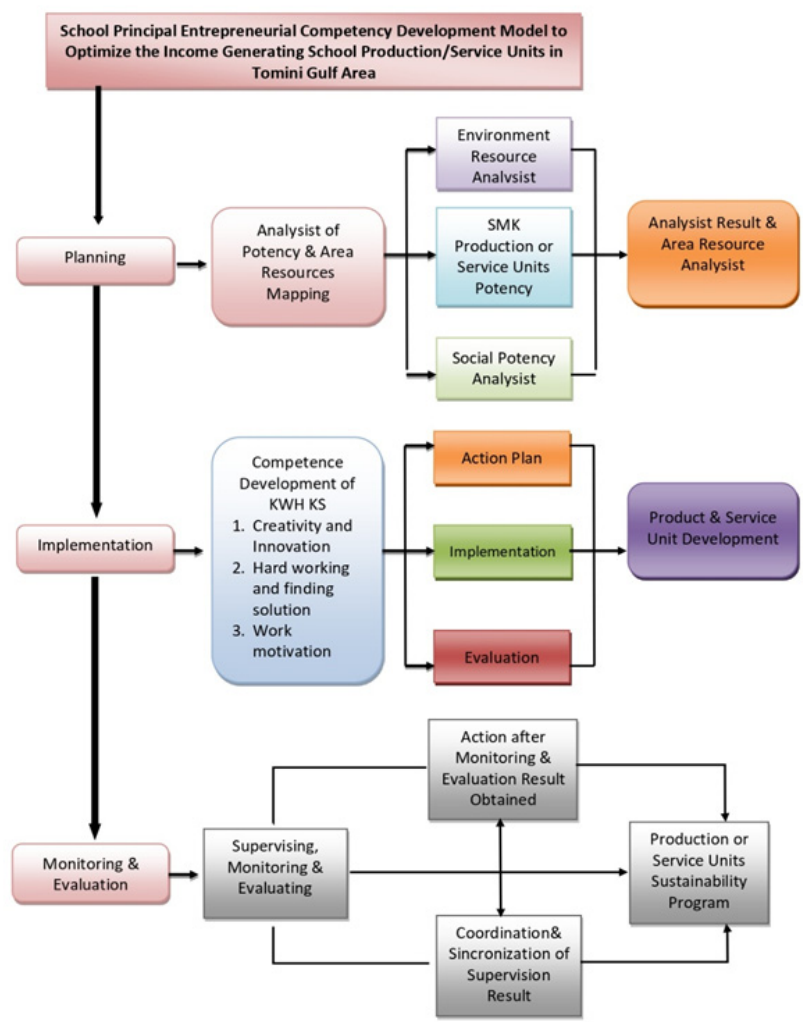

Figure 1: Design Model of Principal Entrepreneurship Competence Development to Optimize Income Generating Production or Service Unitsat of State Vocational High School in Tomini Gulf Area 


\section{Discussion}

\subsection{The Entrepreneurship Potential of the Principal in the Gulf of Tomini}

The results showed that the principal's entrepreneurial potential based on the indicators of creativity and innovation, diligence and finding solutions, work motivation, and entrepreneurial drift were in the good category. This result shows that the principal needs to increase creativity, innovation, motivation, diligence, finding solutions, and entrepreneurial drift to empower the potential of school resources owned in order to optimize the function of production or service units as a learning resource and a source of income generating of the school. This is in line with Usman (2007) that one of the most determining factors to achieve production or service units purposes is the principal's ability to develop the entrepreneurial drift. Ministry of Education RI (2010) stated that entrepreneurship is not only owned by business people but also absolutely owned by workers, especially school principals who are required to have adequate entrepreneurial competence. The ability of the principals to develop creativity and innovate in various aspects is good at finding solutions, diligence, perseverant, and is able to benefit from opportunities to realize school success of the school they led indicates the success of the principal in realizing effective, efficient, productive, and accountable school management. Principals whose entrepreneurial drift reflect on their personality can strengthen the school to have achievement culture sustainability (Rivai, 2010).

For organizations, strategic entrepreneurship synthesizes entrepreneurship and strategically acts simultaneously to optimize the pursuit of opportunities and in turn create profits. Thus, a firm's ability to create value for shareholders increases in terms of novelty and resilience (Monsen \& Boss, 2009); (Sirmon \& Michael, 2003). For society, strategic entrepreneurship contributes through the creation of new values that better meet social needs (Kallas, 2019). Although entrepreneurship education tends to lead to newer focus areas in business education, it has become one of the pioneering business fields in the implementation of contemporary design thinking (Sarooghi et al., 2019); (Lie et al., 2019). The concept of entrepreneurship which orientates towards empowerment is introduced as a cognitive state characterized by meaning, competence, self-determination, and the impact on entrepreneurial activities (Santos et al., 2019). The importance of evaluating educational entrepreneurial outcomes is self-evident. However, the best way to approach the evaluation and what models and measures should be used remain the subject of ongoing academic discussion (Mets et al., 2017).

Entrepreneurship education has progressed from teaching students to start a business to helping them recognize opportunities, manage difficulties, and develop an entrepreneurship based on a rational mindset (Kuratko \& Morris, 2018). Research by Schwartz \& Malach-Pines (2009), found differences between the offerings and expectations of entrepreneurship programs in universities, so that it has important implications for entrepreneurship education in the future. The duties of school leaders become increasingly challenging at the same time being held at a higher level of supervision with less resources (Weathers \& White, 2015). These conditions do not bode well for hiring, developing, and retaining high-quality leaders. Low levels of leadership capacity and instability are closely linked to negative outcomes across the system (Coelli \& Green, 2012), and refining areas have been found to be central to gaining traction in a comprehensive manner to improve teaching and learning (Weathers \& White, 2015).

Ministry of Education Republic of Indonesia regulation in 2007 stated that the entrepreneurial dimensions of school principals are (1) create useful innovations for school development, (2) diligent to achieve school success as an effective learning organization, (3) have strong motivation to succeed in carrying out main tasks and its function as the leader of the education unit, (4) perseverant and always looking for the best solutions in facing the obstacles encountered by schools, and (5) have entrepreneurial drift in managing school/madrasah production/service unit activities as a source of learning for students (Ministry of Education RI, 2007).

Directorate of Vocational Training (2007) stated that 13 characteristics of VHS principals with 
entrepreneurial drift are (1) have an explorer spirit, (2) have high self-confidence, (3) have the courage to take risks, (4) creative and innovative, (5) think positively, (6) have marketing and selling ability, (7) have a strong ambition to be the best, (8) create opportunities, (9) have economic insight, (10) independent, (11) have ethics, (12) able to work hard, and (13) responsive to change.

Some of the values above should be possessed by school principals, particularly VHS principals in order to develop better quality schools. However, Ministry of Education RI (2010) only requires the seven most important values that school principals need to have, particularly those for VHS principals. The seven values are (1) self-confidence, (2) develop positive thoughts, (3) perseverant and being results oriented, (4) learning how to handle risks, (5) have a leadership spirit, (6) develop creative and innovative attitudes, and (7) think ahead.

The description above shows that the most important dimensions of entrepreneurship owned by school principals are creativity and innovation, because the axioms that underlie the entrepreneurial process are challenges to think creatively and act innovatively, thus problems can be resolved and solved. This is in accordance with Overton (2002) who stated that the essence of entrepreneurship is creativity and innovation. Creativity is the ability to create something new which has never existed before. While innovation is the creation of something different from before. Suryana and Gulfu (2011) state that the essence of entrepreneurship is to create added value in the market through the process of combining resources in new and different ways in order to compete. Meanwhile, Zimmerer and Scarborough (1996) stated that added value can be created in the following ways: (1) new technology development, (2) discovery of new knowledge, (3) improvement of existing products (goods and services), (4) invention in different ways to produce higher quantity of products and services with fewer resources.

The school principals need to make breakthroughs and have innovative thoughts continuously to develop the production unit to be more advanced in order to achieve the goals and objectives of establishing a school production unit that has been formulated. This is in accordance with the statement of the Directorate of Vocational Training (2007) that creativity and innovation are very important for school principals to develop production or service units because (1) encourage morale and customer satisfaction, (2) provide understanding to teachers and staff involved in the production unit about the importance of creativity, (3) creativity to encourage the interests and needs of the community, and (4) great commitment from the school principal in an effort to increase the income generating vocational high school production unit in Tomini Gulf area.

The school principal must be able to arouse the creativity of teachers and the school members. The creativity of the school principal as one of the important variables to develop production unit should encourage and ensure the participation of teachers and the entire school community, thus good collaboration can be realized. The commitment of the principal to develop the production unit must be maintained properly and adequately, must exchange knowledge and experience to develop a superior production unit. It must also be built by developing good promotions and collaboration with all parties. This is in line with Hadriah et al. (2019) that the supporting factors for school production unit management are (a) the willingness of all the parties to run production unit activities (b) professional educators, (c) sufficient capital resources, (d) adequate facilities and infrastructure, and (e) clear market share.

The creativity and innovation of school principals that can be developed to become superior VHS production units in Tomini Gulf area, including: (1) generate creativity and innovation of the teachers, thus teachers can be maximally productive to create or develop products/services that are in accordance with school potential and market desires, (2) optimize all the potential of schools and areas into business opportunities, (3) instil the courage to collaborate with the industry or society to develop mutually beneficial business networks, (4) tenacious to find solutions, (5) responsive to change (adaptable), particularly in the development and marketing of products/services, and (6) have a high commitment to jointly promote school production or service units.

Lavesque and McNeil (2003) stated four key success factors that can increase the creativity of teachers and school members, namely: (1) a climate of mutual trust and a shared commitment to 
always learning and developing oneself, (2) honest and open communication, (3) creativity of process, problem solving tools and techniques, and (4) flexible school management processes. Furthermore, Levesque stated eight ways that can be applied to achieve superior performance creative talents of knowledge worker, namely: (1) adventurers, (2) navigators, (3) explorers, (4) visionaries, (5) pilot, (6) inventors, $(7)$ harmonious, and (8) poetic. These methods can be developed by the principal either individually or in combination to arouse the creativity of teachers and school members.

\subsection{Potential School Resources that Can Be Developed as Production or Service Unit}

Based on the results, it shows that the potential school resources that can be developed as income generating VHS production/service units in Tomini Gulf area is human resources, facilities that can be rented out to the community, and a land that can be developed into agricultural land for horticultural crops either directly or by using a greenhouse and hydroponics.

The creativity of the principal to mobilize school resources (teacher and student community) to participate in activities, innovating, solving problems, thinking critically and having entrepreneurial instincts, should be pair with the effort of the principal to set an example of working diligently, thus the principal become a role model for teachers and students to develop all potential resources owned by schools to increase income generating production or service units. The more professional the principal in developing production or service units as a business institution will bring greater benefits for the school, including: (1) obtain independent school funding sources (not solely from the government), (2) create a market climate in schools as a way to overcome problems related to the student practical production results, (3) increase skills, creativity, and professionalism of teachers, and quality of growth, (4) support the improvement of the welfare of school members, it can even be a means of school promotion and an effort to build image of a vocational school. This is in accordance with Sartono (as cited in PMPTK Depdıknas, 2007) that the vocational school production unit is a forum for entrepreneurship which activities must be sustainable, empower school members and their environment as well as be managed professionally in order to bring positive impacts on schools both as a source of learning and as a source of school income. This statement is supported by the results of previous studies (Mas, 2014; Suyitno et al., 2014) that the school principals who have an entrepreneurial spirit will become agents of change because they are able and capable to transform their resources to obtain beneficial added value as in economically, personally, and community organization.

Entrepreneurship education is a tool used in order to develop entrepreneurial activities through the maximum use of resources. According to Bischoff et al. (2018) the key factor of entrepreneurial success is the presence of a leader who is able to combine various resources and encourage entrepreneurial activities in schools in order to increase the income. In addition, entrepreneurship education also requires commitment and support from school management. According to Kourilsky (1995) entrepreneurship education is an introduction to opportunities, arranging resources, and building businesses and in order to develop a proper production or service units, thus the principal needs to learn to allocate resources, use marketing strategies, and utilize money and school members (Jones \& English, 2004).

Some efforts that can be made in order to increase school income are by combining five things related to resources, namely (1) commitment from all parties involved in production or service units, (2) professional educators, (3) capital resources, (4) prepare adequate facilities and infrastructure, and (5) a clear market share (Hadriah et al., 2019). The forum that can be used by VHS to manage these resources is the production unit. The production unit as stated by the Ministry of Education RI (2004) is an effort to accommodate school independent entrepreneurial activities that require special authority from school principals to empower all resources based on academic and financial principles. This is supported by the Decree of the Minister of Education and Culture no 0490/U/1992 Chapter XII article 29 paragraph 1 which explicitly stated that every school at the vocational school level needs to make efforts to have a production unit in its school (Department of Education and 
Culture, 1993). This is a forum for managing and increasing the capacity of school resources and providing added value to schools.

\subsection{Potential Regional Resources that Can Be Developed as Production or Service Unit}

Based on the results of study from three public vocational high school in three regencies in Tomini Gulf area, it shows that the area's most potential resource for development is agriculture at $73 \%$. This indicates that most of area of these three regencies are agricultural areas. Although other potentials such as husbandry, fisheries and tourism also exist in this area which can also support the development of VHS in Tomini Gulf area. Therefore, the principal needs to further improve the development of products sourced from agricultural products, because the majority of VHS in the three regencies have agribusiness processing expertise programs.

In order to ensure that the school has graduates who are needed by the business world and the industrial world and in accordance with regional potential, the establishment of VHS is based on the consideration of area potential, thus it is synchronous between the graduate resources and the potential that can be developed according to their expertise. The philosophy of VHS is contained in Government Regulation Number 29 of 1990 article 3 paragraph (2): "the purpose of vocational secondary education is to prioritize the preparation of students to enter the workforce and develop a professional attitude".

It is also supported by the Directorate of Vocational Training (2017) which stated that every VHS graduate have competencies that are in accordance with the superior potential in their region, thus they can create jobs and generate economic value. In addition, in Government Regulation No. 17 of 2010, it is mentioned about the function of vocational education which stated that VHS equips students with abilities both in science and technology as well as life skills to conform the needs of society. This indicates that the area potential with resources that can be utilized should be part of the implementation of education at VHS to be able to generate graduates who can conform to the needs and the environment.

Efforts can be carried out to develop area potential into vocational education according to Directorate of Vocational Training (2017) are (1) examining the relationship between development levels and VHS, (2) examining the linkages between area potential sectors, (3) VHS contributions to sector or economy, (4) employment, (5) human resource support capacity, and (6) strategic considerations. Several previous studies show some efforts that have been conducted by VHS include (1) animal husbandry aspect. Study conducted by Falefi (2017) on schools in Aceh area with area potential in the field of animal husbandry by establishing beef cattle fattening businesses, (2) agricultural aspect, study conducted by Marina \& Yulistia (2015) at VHS in West Java region by utilizing the potential of agricultural areas though establishing a business of various chips such as cassava leaf chips, carrot chips, lokatmala leaf chips, basil leaf chips, spinach leaf chips, katuk leaf chips and various sticks made from local ingredients. Materials used by the school is leaves that are not used optimally by many people, (3) fishery aspect, study conducted by (Haryati, 2014) at a vocational high school in Central Java which developed a production unit for processing milkfish waste into food products that can be sold namely milkfish spines floss.

From the study distribution in various sectors, it should inspire other vocational high school, especially vocational high school in Tomini Gulf area, because these food ingredients sectors are also found in this area. Thus, it will better utilize the area potential in each region to be synergized with the development of production units, either products or services.

\subsection{The Principal Entrepreneurial Competency Development Model}

The design model found to develop the entrepreneurial competence of school principals to optimize the income generating vocational high school in Tomini Gulf area consists of three stages, namely: planning, implementation, monitoring and evaluation. 
Entrepreneurship Competency Development Planning for Vocational High School is a stage containing an initial study to analyze the potential and mapping of area resources, the principal has formed an institution to carry out analysis, delegate tasks, and plan future strategic. Planning stage is divided into three analysis activities, namely environmental potential analysis, vocational high school production or service units potential analysis, and social potential analysis. The output of three analysis results is in the form of data and mapping of area resources potential.

First, environmental potential analysis. Analyzing the area potential around the school which has geographic characteristics and natural resources. This can be in the form of production raw materials, commodities, or tourism that can be used for the development of vocational high school production or service units.

Second, VHS production or service unit's potential analysis. The findings from the analysis of environmental potential should be adjusted to the resources the school has, starting from the potential of the school community, both teachers and students, school facilities, including practicum laboratories. The various potentials that can be used as a school production unit, it should be synchronized with the analysis of the potential data of the school environment in order to produce appropriate products or services (fulfilling community needs).

Third, analysis of social potential. This is related to the behavior of the community around the school namely interactions, culture, customs and habits. It should be analyzed to determine the methods of product utilization and marketing to the public. From this activity, schools can also find out how the products from their production units are needed by the community or not.

\subsection{Implementation of vocational school principal entrepreneurship competency development.}

The implementation stage is a process that requires an active role for the principal, especially in developing entrepreneurial competence by utilizing their creativity and innovation, diligence and finding solutions, as well as work motivation. These three things should be considered by the principal to develop a product and service unit in his school.

Furthermore, this stage consists of three stages of activity. The results of the analysis and mapping of area resources were then carried out three major activities to develop vocational high school product or services units, namely action plans, implementation and evaluation. Action plans are activities carried out by school members such as preparation including finding product or service ideas, delegating tasks, and strategic plans. This activity will produce a unit of products and services that are in accordance with the regional potential data.

After that, the next activity is to implement the predetermined plan starting from utilizing all resources, doing work according to the target, producing products or services, running the production unit and marketing products/services produced. Implementation activity are expected to be managed adequately, thus at a certain stage of the period, evaluation should be carried out in by vocational high school principal and the development team of production or service units.

Evaluation is the final activity in the development cycle of vocational high school production and service units. The purpose of this activity is to be able to check the results and make an assessment of vocational high school production or service units whether it is already in accordance with the planning targets and ensure that any obstacles encountered can be followed up and be solved.

4.7 Monitoring and evaluation of vocational school principal entrepreneurship competency development.

This stage is carried out in order to collect data, measure it, and assess the implementation of product or service development activities developed by the principal. This activity can be performed 
through three activities, namely monitoring and evaluation, following up on the results, and coordinating and synchronizing the results of supervision. The output of this result is the continuous development of vocational high school production or service units.

The flow of activities of this model should be carried out coherently, because it is a part of management activities and is expected to create production unit that can be developed means not only being established but also can be sustainable in financing education and school operational. VHS business unit development stage is expected to train school principals to be able to develop entrepreneurial competence. Therefore, should the school principal have the determination to develop entrepreneurial competences, one of the methods is to apply this model to support the optimization of school production or service units.

\section{Conclusion}

The entrepreneurial potential of vocational high school principals in Tomini Gulf area is in good category. This indicates that the principal already has a good entrepreneurial drift in terms of creativity, innovation, motivation, diligence, and finding solutions. However, these values need to be improved in order to manage school resources properly to create a superior school.

Potential school resources that can be developed as income generating production or service units include: human resources who are experts in their fields, land available for planting horticultural crops, school facilities and infrastructure that can be rented out to the community. While the potential for area resources that has the most potential to be developed as income generating production or service units is agriculture. Due to the three regencies in Tomini Gulf area are geographically located in an agricultural area, and in general, schools there have an Agribusiness Expertise Program for Agricultural Product Processing (APHP).

The design model school principals' entrepreneurial competence development to optimize income generating VHS production or service units in Tomini Gulf area consists of three stages, namely, planning, implementation, and monitoring and evaluation. Planning includes an analysis of the school potential and area potential which consist of: analysis of the entrepreneurial potential of the principal, the environment potential, school production or service units potential, and social potential. Implementation includes the entrepreneurial development activities of school principals and production or service units. Monitoring and evaluation includes the following activities: supervision, follow-up on monitoring results, coordination and synchronization of the supervision results, as well as the sustainability of the production or service units program.

\section{Recommendations}

The school principals are expected to improve their entrepreneurial competence, especially their creativity and innovation in developing production or service units through optimally empowering the resources, thus can obtain sources of income independently to finance the implementation of education in schools as well as improve the welfare of school members.

Teachers are expected to be more creative, continuously innovate, develop current ideas to create or develop products at production or service units to be more competitive and in demand by the community, and students are expected to always improve their competence and learning independence, thus they have sufficient skills to face the increasing global competition era.

The society is expected to support school production or service units by using products/services produced by schools. Furthermore, school is also expected to create partnerships in the development and marketing of mutually beneficial products.

\section{Limitation and Novelty}

This study is limited to the point of view of principals' entrepreneurial leadership in helping schools 
find additional resources. Therefore, future research is expected to be conducted from different perspectives However, the novelty of this research is that there is no similar model that offers a solution to the problem of new sources of funding for schools that can be used by principals in order to direct them to find other sources of funding other than the use of existing sources. In this study, there are also significant benefits in providing guidance on how to manage the surrounding resources including the potential of the area into a product or service so that it becomes a new alternative in obtaining financial support. By duplicating the method described in this model, it is hoped that the principal, especially around Tomini Bay, will be able to produce various products and services that have sale value and can be marketed what has been found is the result of analysis based on data and processed information from the field.

\section{Acknowledgments}

The author would like to thank Gorontalo State University for funding this study, as well as Office of Education, Culture, Youth, and Sport of Indonesian and all parties for their assistance, thus this study can be carried out.

\section{References}

Birdthistle, N., Costin, Y., \& Hynes, B. (2016). Engendering entrepreneurial competencies in the youth of today: A teacher's perspective. Education \& Training, 58(7/8), 766-782.

Bischoff, K., Volkmann, C., \& Audretsch, D. (2018). Stakeholder collaboration in entrepreneurship education: An analysis of the entrepreneurial ecosystems of European higher educational institutions/s10961-017-9581-0. The Journal of Technology Transfer, 43(1), 20-46.

Capella-Peris, C., Gil-Gómez, J., Martí-Puig, M., \& Ruíz-Bernardo, P. (2020). Development and validation of a scale to assess social entrepreneurship competency in higher education. Journal of Social Entrepreneurship, 11(1), 23-39.

Coelli, M., \& Green, D. A. (2012). Leadership effects: School principals and student outcomes. Economics of Education Review, 31(1), 92-109.

Department of Education and Culture. (1993). Decree of the Minister of Education and Culture of the Republic of Indonesia Number 0490 / U / 1992 concerning vocational high schools. Jakarta: Directorate of Vocational Secondary Education, Ministry of Education and Culture of Republic of Indonesia.

Directorate of Vocational Training. (2007). Implementation guidelines 2007: Development assistance for production. Jakarta: Directorate General of Primary and Secondary Education, Ministry of Education and Culture of Republic of Indonesia.

Directorate of Vocational Training. (2017). Guidelines for synchronizing expertise in vocational high schools with priority for regional leading potential and manpower. Jakarta: Directorate of Vocational Secondary Education, Ministry of Education and Culture of Republic of Indonesia.

Duval-Couetil, N. (2013). Assessing the impact of entrepreneurship education programs: Challenges and approaches. Journal of Small Business Management, 51(3), 394-409.

Falefi, A. (2017). Prospek usaha penggemukan sapi potong di unit usaha penggemukan sapi potong SMK PPNegeri Saree Kabupaten Aceh Besar [Beef cattle fattening business prospects in beef cattle fattening business unit at SMK PP-Negeri Saree, Aceh Besar District]. Aceh: Syiah Kuala University.

Gall, M. D., Borg, W.R., Gall., J. P. (2003). Educational research: An Introduction. 7 ed. New York: Pearson.

Hadriah, S., Munandar, A., \& Faridah, F. (2019). Manajemen unit produksi sekolah di SMK Negeri 8 Makassar [Management of school production unit at SMK Negeri 8 Makassar]. Jurnal Administrasi Pendidikan, 26(1), 129-140.

Haryati, S. (2014). Peningkatan kreativitas berwirausaha siswa kelas XII jasa boga 1 dalam pengolahan limbah bandeng sebagai peluang usaha melalui unit produksi di SMK Negeri 1 Pati [Increasing Entrepreneurial Creativity for Class XII Students in catering services 1 in Pati]. Jurnal Pendidikan Ilmu Sosial, 24(2), 57-84.

Iwu, C. G., Opute, P. A., Nchu, R., Eresia-Eke, C., Tengeh, R. K., Jaiyeoba, O., \& Aliyu, O. A. (2019). Entrepreneurship education, curriculum and lecturer-competency as antecedents of student entrepreneurial intention. International Journal of Management Education, February, 100295.

Jackson, T. (2015). Entrepreneurship training in tertiary education: Its development and transfer. Local Economy, 30(5), 484-502. 
Jones, C., \& English, J. (2004). A contemporary approach to entrepreneurship education. Education + Training, $46(8 / 9), 416-423$.

Kallas, E. (2019). Environment-readiness entrepreneurship intention model: The case of Estonians and the Russian-speaking minority in Estonia. SAGE Open, 9(1).

Kourilsky, M. (1995). Entrepreneurship education: Opportunity in search of curriculum, center for entrepreneurial leadership, Ewing Marion Kauffman Foundation. Missouri: Ewing Marion Kauffman Foundation.

Kuratko, D. F., \& Morris, M. H. (2018). Examining the future trajectory of entrepreneurship. Journal of Small Business Management, 56(1), 11-23.

Lavesque, P., \& McNeil, A. (2003). Dreamcrafting: The Art of dreaming big, the science of making it happen paperback - illustrated. Oakland: Berrett-Koehler Publishers.

Lie, D., Sudirman, A., Efendi, E., \& Butarbutar, M. (2019). Analysis of mediation effect of consumer satisfaction on the effect of service quality, price and consumer trust on consumer loyalty. International Journal of Scientific \& Technology Research, 8(8), 421-428.

Marina, I., \& Yulistia, I. (2015). Strategi pengembangan agribisnis hasil pertanian melalui inovasi dan kreatifitas menjadi produk unggulan di SMK Negeri 1 Pacet Kabupaten Cianjur [The agribusiness development strategy of agricultural products through innovation and creativity to be a superior product at SMK Negeri 1 Pacet, Cianjur Regency.]. Mimbar Agribisnis, 1(1), 45-54.

Marniati, \& Witcjaksono, A. D. (2020). Curriculum implementation, entrepreneurship motivation, and fashion entrepreneurship - case study of student learning outcomes in regular classes and entrepreneurship classes. International Journal of Fashion Design, Technology and Education, 13(3), 317-324.

Mas, S. R. (2014). The implementation of the school principal's entrepreneurship competency in the management of educational hotel. International Journal Applied Business and Economic Research, 1(4), 1331-1342.

Mas, S. R. (2015). Pembinaan kompetensi kewirausahaan siswa SMKN 1 Limboto Kabupaten Gorontalo [Development of entrepreneurship competence for students of SMKN 1 Limboto, Gorontalo Regency]. Jurnal Manajemen Pendidikan, 7(1), 107-120.

Mas, S.R., \& Suking, A. (2020). Entrepeneurship Competence of School Principals to Support the Development of Income Generating Production Units. International Journal of Innovation, Creativity, and Change, $12(10), 245^{-257}$

Mets, T., Kozlinska, I., \& Raudsaar, M. (2017). Patterns in entrepreneurial competences as the perceived learning outcomes of entrepreneurship education: The case of Estonian HEIs. Industry and Higher Education, 31(1), 23-33.

Ministry of Education RI. (2004). Manual standard for vocational secondary education manual. Jakarta: Ministry of Education of Republic of Indonesia.

Ministry of Education RI. (2007). Regulation of the Minister of National Education of the Republic of Indonesia Number 13 of 2007 concerning Standards for School/Madrasah Principals. Jakarta: Ministry of Education of Republic of Indonesia.

Ministry of Education RI. (2010). Training materials for strengthening learning methodologies based on cultural values to form nation competitiveness and national character: Entrepreneurship education development. Jakarta: Research and Development Agency for Curriculum Center of Ministry of Education of the Republic of Indonesia.

Monsen, E., \& Boss, R. W. (2009). The impact of strategic entrepreneurship inside the organization: Examining job stress and employee retention. Entrepreneurship Theory and Practice, 2000, 71-105.

Overton, Rodney. (2002). Are you an entrepreneurship: Tips, quizzes, case studies and tests to improve your entrepreneurial skills/Rodney Overton. Singapore: Wharton Books.

Piperopoulos, P., \& Dimov, D. (2015). Burst bubbles or build steam? Entrepreneurship education, entrepreneurial self-efficacy, and entrepreneurial intentions. Journal of Small Business Management, 53(4), 970-985.

PMPTK Depdiknas. (2007). Manajemen unit produksi/jasa sebagai sumber belajar siswa dan penggalian dana pendidikan persekolahan [Management of production / service units as a source of student learning and raising school education funds]. Jakarta: PMPTK Depdiknas.

Rivai, H. V. (2010). Manajemen sumber daya manusia untuk perusahaan dan teori ke praktek [Human resource management for companies and theory to practice]. Depok: Rajawali Press.

San-Martín, P., Fernández-Laviada, A., Pérez, A., \& Palazuelos, E. (2019). The teacher of entrepreneurship as a role model: Students' and teachers' perceptions. International Journal of Management Education, August, 100358.

Santos, S. C., Neumeyer, X., \& Morris, M. H. (2019). Entrepreneurship education in a poverty context: An empowerment perspective. Journal of Small Business Management, 57(S1), 6-32. 
Sarooghi, H., Sunny, S., Hornsby, J., \& Fernhaber, S. (2019). Design thinking and entrepreneurship education: Where are we, and what are the possibilities? Journal of Small Business Management, 57( $\left.\mathrm{S}_{1}\right), 78-93$.

Schwartz, D., \& Malach-Pines, A. (2009). Entrepreneurship education for students: How should universities prepare for the challenge of teaching entrepreneurship? Industry and Higher Education, 23(3), 221-231.

Sirmon, D., \& Michael, H. (2003). Family firms through managing resources: Linking unique resources, management, and wealth creation in family firms. Entrepreneurship Theory and Practice, 27(4), 339-358.

Suryana, Y., \& Bayu, K. (2011). Kewirausahaan pendekatan karakteristik wirausahawan sukses (Entrepreneurship approach characteristics of successful entrepreneurs). Jakarta: Kencana Prenada Media Group.

Suyitno, S. (2018). Strategi kepemimpinan kepala sekolah berjiwa wirausaha [Entrepreneurial principal leadership strategy]. Journal Aplikasi Administrasi, 21(2), 121-137.

Suyitno, S., Sonhadji, A., Arifin, I., \& Ulfatin, N. (2014). Entrepreneurial leadership of vocational schools principals in Indonesia. International Journal of Learning \& Development, 4(1), 45-64.

Usman, H. (2007). Manajemen unit produksi/jasa sebagai sumber belajar siswa dan penggalian dana pendidikan persekolahan: Bahan diklat kepala sekolah [Management of production/service units as a source of student learning and funds for school education: School principal training]. Jakarta: Department of National Education.

Weathers, J. M., \& White, G. P. (2015). Leading Small and Mid-Sized Urban School Districts. UK: Emerald.

Wurthmann, K. (2014). Business students' attitudes toward innovation and intentions to start their own businesses. International Entrepreneurship and Management Journal, 10(4), 691-711. https://doi.org/10.1007/s11365-013-0249-4

Zimmerer, T., \& Scarborough, N. (1996). Entrepreneurship the new venture. New York: Pearson College Division. 